\title{
MEASUREMENT OF PROSTATIC ACID PHOSPHATASE BY GEL DIFFUSION METHODS
}

\author{
SIDNEY SHULMAN, LOUISE MAMROD, RAYMOND W. LANG, \\ MAURICE J. GONDER AND WARD A. SOANES
}

\begin{abstract}
Department of Bacteriology and Immunology, State University of New York at Buffalo, School of Medicine, Buffalo VA Hospital, Millard Fillmore Hospital Research Institute, and Urological Research Foundation, Buffalo, Nerw York
\end{abstract}

(Received 20th October 1964)

\begin{abstract}
Summary. Prostatic acid phosphatase can be detected in individual human prostatic fluids by means of gel diffusion antigen-antibody precipitation with specific staining procedures. The fluids can be diluted to various degrees before the reaction fails. This titre, or limiting dilution, ranged from $1: 64$ to $1: 16,000$. It paralleled the results obtained by the King-Armstrong assay of enzyme activity. Gel diffusion analysis revealed the presence of two antigens with acid phosphatase activity.
\end{abstract}

\section{INTRODUCTION}

Human prostatic fluid has been investigated by physico-chemical methods (Soanes, Gabrieli \& Felch, 1961; Shulman, Bronson, Gonder \& Soanes, 1963; Soanes, Shulman, Mamrod, Gonder \& Barnes, 1963). Several immunological and immunochemical studies have also been published on this fluid (Barnes, Soanes, Mamrod, Gonder \& Shulman, 1963a, b), and on the prostatic tissue (Flocks, Urich, Patel \& Opitz, 1960; Flocks, Bandhaur, Patel \& Begley, 1962). A recent report has indicated that antigen-antibody reactions carried out in gel diffusion can be modified to reveal the presence of the prostatic acid phosphatase (Mamrod, Shulman, Gonder \& Soanes, 1964). A detailed procedure has been published (Shulman, Mamrod, Gonder \& Soanes, 1964). Further studies have now been made to explore the variation in levels of this antigen in various samples of human prostatic fluid.

\section{MATERIALS AND METHODS}

Prostatic fluid was obtained by rectal massage from patients with prostatic disease and also from normal individuals. This diagnostic distinction was based on manual palpation. The samples were all centrifuged at $15,000 \mathrm{rev} / \mathrm{min}$ on the SS-34 rotor of a Servall centrifuge $(27,000 \mathrm{~g})$ for $30 \mathrm{~min}$ to remove debris. The clear samples were kept frozen until required for analysis. Their concentration of protein was determined by the biuret method (Gornall, Bardawill \& David, 1949). Rabbit antisera to human prostatic fluid ( $R$ 1698) and to human blood serum ( $R$ 1699) were prepared by inoculation of New Zealand 
White rabbits intraperitoneally with $1.0 \mathrm{ml}$ of pooled samples of human prostatic fluid or with $0.5 \mathrm{ml}$ of normal human serum, three times a week for 4 weeks. Blood samples were taken 1 week after the last injection. A second antiserum to prostatic fluid was a pool of several antisera, prepared by a similar schedule of inoculations. Immunodiffusion was done with the use of $1 \%$ agar in barbital buffer $\mathrm{pH} 8.2$, using a modification of Ouchterlony's procedure. Glass plates, $5 \times 7$ in., were used in some experiments; microscope slides, in others. The agar layer was $2 \cdot 2 \mathrm{~mm}$ thick. Wells were punched out with a hypodermic needle so as to contain 12 to $15 \mu \mathrm{l}$, and spaced in a suitable geometric pattern; on the large plates this consisted of a series of antigen dilutions lined up in parallel rows along series of wells containing samples of the antiserum, so that the distance between nearest antigen and antibody wells was $5 \mathrm{~mm}$, centre to centre. After permitting precipitation to occur for $48 \mathrm{hr}$, the plates were washed in a saline solution for 5 days at room temperature. This was followed by staining. The methods of staining for protein and phosphatase have been described (Shulman et al., 1964).

The acid phosphatase staining, an adaptation of the Gomori histochemical procedure (MacManus \& Mowry, 1960), involved the use of $0.05 \mathrm{M}$-acetic acid-sodium acetate buffer, $\mathrm{pH} 5 \cdot 0$, plus lead nitrate at a concentration of $1.33 \mathrm{~g} / \mathrm{l}$. The substrate was sodium $\beta$-glycerophosphate $(52 \%)$ freshly dissolved in water at a concentration of $3 \%$. After incubation in the presence of buffersubstrate mixture, usually for 10 to $15 \min (10: 1, v / v)$ at $37^{\circ} \mathrm{C}$, the plates were rinsed in distilled water, then immersed in $1 \%$ acetic acid for $1 \mathrm{~min}$, again in water, and finally in $2 \%$ yellow ammonium sulphide for 1 to $2 \mathrm{~min}$.

Fluid assay of phosphatase activity was based on Kintner's modification of the King-Armstrong method (Kintner, 1951). Each sample was diluted $1: 10,000$ with saline $(0 \cdot 15 \mathrm{M}-\mathrm{NaCl})$ and assayed immediately. The substrate was phenyl phosphate, and the incubation period $15 \mathrm{~min}$. Liberated phenol was measured colorimetrically, using the Folin-Ciocalteu reagent. The results were expressed in 'extrapolated' King-Armstrong (K-A) units, one K-A unit denoting the liberation of $1 \mathrm{mg}$ of phenol/1 hr. Our data, based on 1 -hr of incubation, were multiplied by four to give the numbers of units. These values may, therefore, be higher than would be obtained from a $1 \mathrm{hr}$ incubation. The tests did not involve the addition of either formaldehyde or alcohol, since prostatic fluid, not blood serum, was being examined.

\section{RESULTS}

A typical pattern of immunodiffusion precipitation can be seen in Pl. 1, Fig. 1, where the antigen-antibody reaction has been intensified by means of acid

EXPLANATION OF PLATE 1

FIG. 1. Gel diffusion precipitation patterns of human prostatic fluid (PF) tested against rabbit antiserum to human prostatic fluid (R 1698) and normal rabbit serum (NRS). The wells were filled as follows: (1) PF 641, (2) PF 635, (3) NRs, (4) R 1698.

FIG. 2. Gel diffusion precipitation patterns of human prostatic fluid tested against rabbit antiserum to human prostatic fluid. Staining has been done first for acid phosphatase and then for other proteins (using Light Green SF). The prostatic fluid was PF 635 with a protein concentration of $2.46 \%$. The wells were filled as follows: (1), (2), (3), (4), (5), (6), $\mathrm{PF}$ at the following dilutions, respectively: $1: 1,1: 4,1: 8,1: 16,1: 32,1: 64 ;(7)$, (8), (9), rabbit antiserum R 1698; (10), normal human serum. 
PLATE 1

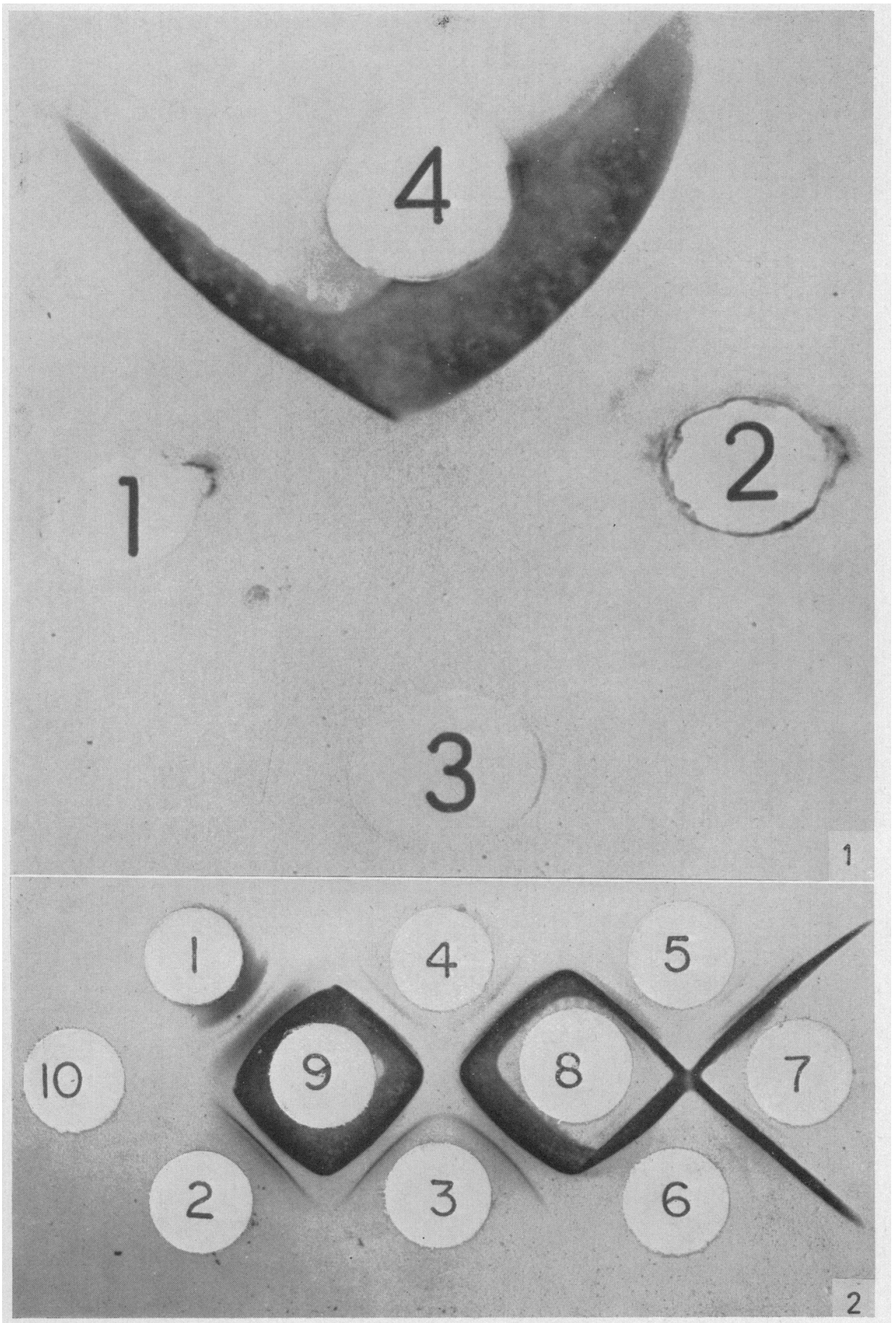

(Facing p. 56) 
PLATE 2

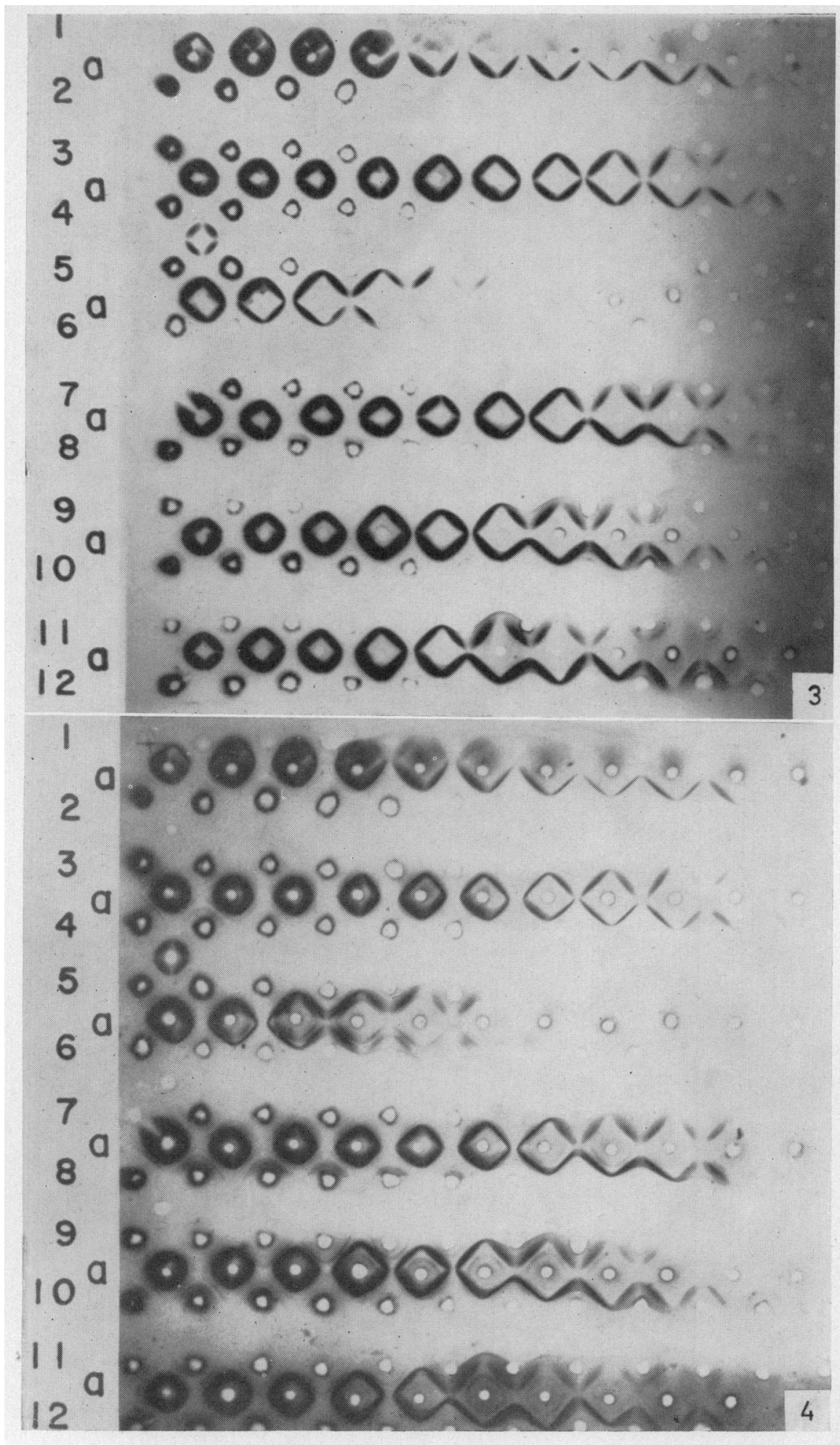


phosphatase staining only. Two individual prostatic fluids, undiluted, have been tested against rabbit antiserum and against normal rabbit serum. In Pl. I, Fig. 2, a sample of prostatic fluid has been tested at various dilutions, and it can be seen that, even at $1: 64$, there is still a strong reaction. Obviously, this sample could have been diluted even further and still remained positive. In the various figures, the broad, dense and speckled lines were brown in the original agar pattern, and the narrow lines were green. It can be seen from Pl. 1, Fig. 2 that there are two bands of precipitation that stain for acid phosphatase,

TABLE 1

ACID PHOSPHATASE LEVELS IN HUMAN PROSTATIC FLUID AS REVEALED BY GEL DIFFUSION TITRATION AND BY KING-ARMSTRONG (K-A) ASSAY

\begin{tabular}{|c|c|c|c|c|c|c|}
\hline \multirow{3}{*}{$\begin{array}{c}\text { Sample } \\
\text { No. }\end{array}$} & \multirow{3}{*}{ Name } & \multirow{3}{*}{ Date (1963) } & \multirow{3}{*}{$\begin{array}{c}\text { Protein } \\
(\%)\end{array}$} & \multicolumn{3}{|c|}{ Acid phosphatase } \\
\hline & & & & \multicolumn{2}{|c|}{ Gel diffusion } & \multirow{2}{*}{$\underset{\mid K l}{K-A \text { units }}$} \\
\hline & & & & $\begin{array}{l}\text { Major } \\
\text { band }\end{array}$ & $\begin{array}{l}\text { Minor } \\
\text { band }\end{array}$ & \\
\hline $\begin{array}{r}1 \\
2 \\
3 \\
4 \\
5 \\
6 \\
7 \\
8 \\
9 \\
10 \\
11 \\
12\end{array}$ & $\begin{array}{l}\text { Arb. } \\
\text { Ruc. } \\
\text { Bur. } \\
\text { Fal. } \\
\text { Gol. } \\
\text { Cos. } \\
\text { Fal. } \\
\text { Smi. } \\
\text { Old. } \\
\text { Eld. } \\
\text { Old. } \\
\text { Sch. }\end{array}$ & $\begin{array}{c}\text { 10th Sept. } \\
\text { 28th Oct. } \\
\text { 5th Nov. } \\
\text { 21st Oct. } \\
\text { 10th Sept. } \\
\text { 11th Nov. } \\
\text { 28th Oct. } \\
\text { 6th Nov. } \\
\text { 29th Oct. } \\
\text { 6th Nov. } \\
\text { 5th Nov. } \\
\text { 6th Nov. }\end{array}$ & $\begin{array}{l}0 \cdot 3 \\
2 \cdot 1 \\
3 \cdot 5 \\
1 \cdot 4 \\
1 \cdot 8 \\
0 \cdot 8 \\
1 \cdot 8 \\
2 \cdot 0 \\
2 \cdot 0 \\
1 \cdot 4 \\
2 \cdot 2 \\
1 \cdot 4\end{array}$ & $\begin{array}{ll}1 & : 64 \\
1 & : 2048 \\
1 & : 1024 \\
1 & : 2048 \\
1 & : 64 \\
1 & : 128 \\
1 & : 4096 \\
1 & : 2048 \\
1 & : 512 \\
1 & : 2048 \\
1 & : 4096 \\
1 & : 4096\end{array}$ & $\begin{array}{l}-\overline{1} \\
1: 1 \\
1: 1 \\
1: 4 \\
- \\
1: 1 \\
\overline{1}: 16 \\
1: 1 \\
1: 8 \\
1: 4 \\
1: 8\end{array}$ & $\begin{array}{r}390 \\
6000 \\
750 \\
3300 \\
620 \\
0 \\
\text { i.s. } \\
3100 \\
1300 \\
3800 \\
4000 \\
2800\end{array}$ \\
\hline
\end{tabular}

Condition of all individuals was chronic prostatitis or benign prostatic hypertrophy.

i.s. $=$ Insufficient sample.

Any K-A value of $O$ was determined at the $1: 10,000$ dilution; the sample may have been positive at smaller dilutions.

although there are as many as six bands of precipitation altogether. One of these two phosphatase bands is a dense band, located midway between the antibody and antigen wells, and the other is a fainter band on the periphery of the antigen well or very close to it. This fainter band can only be seen at a dilution not greater than $1: 4$. It was noticed that samples from different individuals could be diluted to different end points, before reaching the point of disappearance of the major phosphatase component. This is illustrated in Pl. 2, Fig. 3, where in twelve samples antigen-antibody reactions have been

\section{EXPLANATION OF PLATE 2}

FIG. 3. Gel diffusion precipitation patterns of human prostatic fluid tested against rabbit antiserum to human prostatic fluid (R 1698). Each numbered row contains a dilution series from a different individual; the dilutions are: $1: 1,1: 4,1: 8,1: 16,1: 32,1: 64$, $1: 128,1: 256,1: 512,1: 1024,1: 2048,1: 4096$. Each row labelled ' $a$ ' contains portions of the undiluted antiserum. The total plate has been stained for acid phosphatase. FIG. 4. Gel diffusion precipitation patterns. This is the same plate as shown in Fig. 3, but subsequently stained with Light Green sF. 
followed by means of acid phosphatase staining only. In Pl. 2, Fig. 4 the same plate is shown after it had been counter-stained with Light Green SF. Table 1 lists the data for the twelve samples and gives the greatest dilution at which the major and minor band could still be seen. This dilution end-point is compared with the total protein concentration, and the level of acid phosphatase activity, as determined by the King-Armstrong method. With one exception, the values were in the range of 390 to $6000 \mathrm{~K}-\mathrm{A}$ units $/ 1 \mathrm{ml}$, showing a considerable spread of activity. Similarly, the limiting dilution in antigen titration for the major phosphatase band also showed wide variation; in this group the lowest value was 1:64 and the highest 1:4096. The minor band could be seen after

TABLE 2

ACID PHOSPHATASE LEVELS IN HUMAN PROSTATIC FLUID AS REVEALED BY GEL DIFFUSION TITRATION AND BY KING-ARMSTRONG (K-A) ASSAY

\begin{tabular}{|c|c|c|c|c|c|c|c|}
\hline \multirow{3}{*}{$\begin{array}{c}\text { Sample } \\
\mathcal{N}_{0} .\end{array}$} & \multirow{3}{*}{ Condition } & \multirow{3}{*}{ Name } & \multirow{3}{*}{$\begin{array}{c}\text { Date } \\
(1963)\end{array}$} & \multirow{3}{*}{$\begin{array}{r}\text { Protein } \\
(\%)\end{array}$} & \multicolumn{3}{|c|}{ Acid phosphatase } \\
\hline & & & & & \multicolumn{2}{|c|}{ Gel diffusion } & \multirow{2}{*}{$\underset{\mid m l}{K-A \text { unit }}$} \\
\hline & & & & & $\begin{array}{c}\text { Major } \\
\text { band }\end{array}$ & $\begin{array}{c}\text { Minor } \\
\text { band }\end{array}$ & \\
\hline $\begin{array}{r}1 \\
2 \\
3 \\
4 \\
5 \\
6 \\
7 \\
8 \\
9 \\
10 \\
11\end{array}$ & $\begin{array}{l}\mathbf{N} \\
\mathbf{N} \\
\mathbf{P} \\
\mathbf{P} \\
\mathbf{N} \\
\mathbf{N} \\
\mathbf{N} \\
\mathbf{N} \\
\mathbf{N} \\
\mathbf{P} \\
\mathbf{P}\end{array}$ & $\begin{array}{l}\text { Mim. } \\
\text { Rus. } \\
\text { Ehr. } \\
\text { Fau. } \\
\text { Mil. } \\
\text { Cun. } \\
\text { Mur. } \\
\text { Zam. } \\
\text { Hen. } \\
\text { Ben. } \\
\text { Kau. }\end{array}$ & $\begin{array}{l}\text { 24th Aug. } \\
\text { 30th July } \\
\text { Ist Aug. } \\
\text { 13th Aug. } \\
\text { 27th Aug. } \\
\text { 6th Sept. } \\
\text { 24th Aug. } \\
\text { 26th Aug. } \\
\text { 24th Aug. } \\
\text { 1st Aug. } \\
\text { 30th July }\end{array}$ & $\begin{array}{l}2 \cdot 7 \\
\text { i.s. } \\
5.4 \\
4 \cdot 3 \\
\text { i.s. } \\
1.3 \\
\text { i.s. } \\
\text { i.s. } \\
\text { i.s. } \\
1.5 \\
3 \cdot 1\end{array}$ & $\begin{array}{ll}1 & : 2048 \\
1 & : 64 \\
1 & : 128 \\
1 & : 2048 \\
1 & : 1024 \\
1 & : 64 \\
1 & : 1024 \\
1 & : 16384 \\
1 & : 4096 \\
1 & : 512 \\
1 & : 8192\end{array}$ & $\begin{array}{ll}1 & : 8 \\
1 & : 4 \\
1 & : 4 \\
1 & : 8 \\
1 & : 4 \\
- & \\
1 & : 16 \\
1 & : 16 \\
1 & : 32 \\
1 & : 4 \\
1 & : 32\end{array}$ & $\begin{array}{l}648 \\
104 \\
44 \\
408 \\
\text { i.s. } \\
0 \\
\text { i.s. } \\
1184 \\
\text { i.s. } \\
424 \\
424\end{array}$ \\
\hline
\end{tabular}

i.s. = Insufficient sample.

Any K-A value of $O$ was determined at the $1: 10,000$ dilution; the sample may have been positive at smaller dilutions.

Condition: $\mathrm{N}$, normal prostate; $\mathrm{P}$, chronic prostatitis or benign prostatic hypertrophy.

dilution in a few samples only and generally at a dilution not exceeding $1: 4$ or $1: 8$. There seems to exist some degree of correlation between values obtained by phosphatase assay and by titration in gel diffusion with respect to the major enzyme component. For example, the three lowest $\mathrm{K}-\mathrm{A}$ values (samples 1,5 and 6 ) had antigen titration values of $1: 64$ or $1: 128$. The next higher K-A levels (samples 3 and 9) corresponded to titration values of $1: 512$ or $1: 1024$. Finally, the highest K-A levels (samples 2, 4, 8, 10,11,12) corresponded to titration values of $1: 2048$ or $1: 4096$. The titration results for the minor band also exhibited some degree of proportionality; a titre higher than I : 1 for the minor component was obtained only when the major band had a titre of $1: 2048$ or higher. It may be noted that the two pairs of samples came from two individuals. While the phosphatase level remained rather constant for one (Fal.), it showed a significant increase for the other (Old.). Interestingly 
enough, this increase was almost exactly the same (four-fold) by both methods of measurement, and even by both the major and minor bands.

A similar set of experiments was done on another group of samples, including this time normal, as well as pathological, materials. The results are shown in Table 2. Here, the K-A levels ranged from 44 to 1184 and, in more or less parallel fashion, the antigen titration values ranged from $1: 64$ to $1: 16384$. This highest dilution value was in fact obtained for a normal sample. It did, however, correspond to the highest $\mathrm{K}-\mathrm{A}$ value in the group.

\section{DISCUSSION}

It has been understood for a long time that acid phosphatase activity is found in prostatic fluid. This has been well reviewed by Huggins (1945) and more recently, by Hoffman (1959). As part of a programme of study of prostatic fluid, immunological methods of characterization have been used. Appropriate staining of the precipitin bands formed in gel diffusion experiments showed that the acid phosphatase activity was present in one major and one minor component, the staining being completely inhibited by tartaric acid, which is to be expected for the prostatic, but not for plasma or erythrocyte, acid phosphatase (Shulman $\mathrm{et} \mathrm{al.,} \mathrm{1964).} \mathrm{This} \mathrm{fact} \mathrm{provided} \mathrm{additional} \mathrm{evidence} \mathrm{that} \mathrm{the} \mathrm{staining}$ procedure indicates phosphatase activity. Immunological control experiments included the use of normal rabbit serum in place of the antiserum, and human serum in place of prostatic fluid; they were negative with respect to phosphatase staining.

The special advantage of the immunochemical procedure derives from the possibility of detecting 'polydispersity' of the enzyme: the presence of the two bands indicates the occurrence of two molecular forms of prostatic acid phosphatase. This conclusion agrees with the observation that the two bands show different mobilities when studied by immunoelectrophoresis (Shulman et al., 1964). Recent experiments have revealed, in fact, that as many as four or five phosphatase components can be resolved by gel diffusion methods, in studying samples of prostatic fluid and prostate extract (Shulman \& Ferber, 1965, unpublished observations).

The gel diffusion method also permits the evaluation of the concentration of the enzyme in each sample by means of the dilution technique and titration. The end-point thus obtained varied considerably from one sample to another sample. It showed no obvious relationship to the total protein concentration, but was roughly correlated with the values obtained by the King-Armstrong type of assay. It appeared to matter little whether the samples came from individuals with a normal or abnormal prostate gland. In fact, the seven normal fluids exhibited the entire range of values, from $1: 64$ to $1: 16000$.

\section{ACKNOWLEDGMENTS}

We wish to thank Susan Kozmycz for valuable assistance with photography. This work was supported by a grant from the John A. Hartford Foundation, Inc. One of us (S.S.) was the recipient of a Research Career Award (K6-AI1377) from the U.S. Public Health Service. 


\section{REFERENCES}

Barnes, G. W., Soanes, W. A., Mamrod, L., Gonder, M. J. \& Shulman, S. (1963a) Immunologic studies of prostatic fluid. Fed. Proc. 22, 498.

Barnes, G. W., Soanes, W. A., Mamrod, L., Gonder, M. J. \& Shulman, S. (1963b) Immunologic properties of human prostatic fluid. F. Lab. clin. Med. 61, 578 .

Flocks, R. H., Bandhaur, K., Patel, C. \& Begley, B. J. (1962) Studies on spermagglutinating antibodies in antihuman prostate sera. 7. Urol. 87, 475.

Flocks, R. H., Urigh, V. G., PAtel, C. A. \& Opitz, J. M. (1960) Studies on the antigenic properties of prostatic tissue. I. 7. Urol. 84, 134.

Gornall, A., Bardawill, C. \& David, M. (1949) Determination of serum proteins by means of the biuret reaction. F. biol. Chem. 177, 751 .

Hofrman, W. S. (1959) The biochemistry of clinical medicine, chap. 12. Year Book Publishers, Chicago.

Hugarns, C. (1945) The physiology of the prostate gland. Physiol. Rev. 25, 281.

KINTNER, E. P. (1951) The estimation of prostatic phosphatase using a modified King-Armstrong method by determining the formaldehyde stable and alcohol labile fraction of serum acid phosphatase. 7. Lab. clin. Med. 37, 637.

MacManus, J. F. A. \& Mowry, R. (1960) Staining methods: histologic and histochemical, p. 163. Hoeber, New York.

Mamrod, L., Shulman, S., Gonder, M. J. \& Soanes, W. A. (1964) Acid phosphatase in prostatic fluid: immunochemical studies. Fed. Proc. 23, 487.

Shutman, S., Bronson, P., Gonder, M. J. \& Soanes, W. A. (1963) Ultracentrifugal constituents of human and canine prostatic fluid. Nature, Lond. 197, 58.

Shulman, S., Mamrod, L., Gonder, M. J. \& Soanes, W. A. (1964) The detection of prostatic acid phosphatase by antibody reactions in gel diffusion. $\mathcal{F}$. Immunol. $93,474$.

Soanes, W. A., Gabrieli, E. R. \& Felch, K. H. (1961) Biochemical classification of prostatitis: based on electrophoretic study of prostatic fluid. 7 . Urol. 85, 621 .

Soanes, W. A., Shulman, S., Mamrod, L., Gonder, M. J. \& Barnes, G. W. (1963) Electrophoretic analysis of prostatic fluid. Classification according to agar gel electrophoresis. Invest. Urology, 1, 269. 